\title{
Enhancement of Stress-Induced Increase in Hypothalamic Noradrenaline Turnover by Pretreatment with Naloxone in Rats
}

\author{
MASATOSHI TANAKA, YASUKO KOHNO, RYOICHI NAKAGAWA, \\ YOSHISHIGE IDA, KENICHIRO IIMORI, YOSHIO HOAKI, \\ AKIRA TSUDA AND NOBUYUKI NAGASAKI \\ Department of Pharmacology, Kurume University School of Medicine, \\ Kurume, 830 Japan
}

Received for publication September 24, 1981

\begin{abstract}
Summary: The relationship between the increase in noradrenaline (NA) turnover and endogenous opioid peptides in the hypothalamus under stressful situations was investigated in rats using a specific antagonist of lopioids, naloxone. Male Wistar rats were in jected subcutaneously with saline, naloxone at $1 \mathrm{mg} / \mathrm{kg}$ or $5 \mathrm{mg} / \mathrm{kg} 10 \mathrm{~min}$ before exposure to immobilization stress for 1 hour. Levels of NA and its major metabolite, 3-methoxy-4-hydroxyphenylethyleneglycol sulfate (MHPG-SO ${ }_{4}$ ) in the hypothalamus were determined fluorometrically. Immobilization stress caused both significant decrease in NA level and increase in MHPG-SO 4 level in rats treated with saline, naloxone at $1 \mathrm{mg} / \mathrm{kg}$ and $5 \mathrm{mg} / \mathrm{kg}$ in comparison to controls. In spite of the finding that $5 \mathrm{mg} / \mathrm{kg}$ of naloxone by itself significantly reduced hypothalamic NA level, pretreatment with $5 \mathrm{mg} / \mathrm{kg}$ of the drug significantly enhanced both

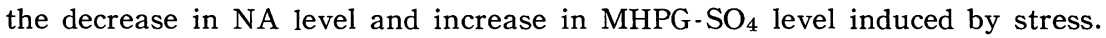
Enhancement of the stress-induced increase in the hypothalamic NA turnover is believed to be due to blockade of opiate receptors by the drug. These results suggest that endogenous opioid peptides in the hypothalamus might be partially involved in stress process by attenuating the increase in NA turnover induced by stress.
\end{abstract}

Key words: immobilization stress - naloxone - noradrenaline - MHPG$\mathrm{SO}_{4}$ - endogenous opioids - hypothalamus

\section{Introduction}

A variety of stressful stimuli are generally accepted to activate the brain noradrenergic system in many species (Stone, 1975).

By simultaneously measuring levels of noradrenaline (NA) and its major metabolite, 3 - methoxy - 4 - hydroxyphenylethyleneglycol sulfate (MHPG-SO ${ }_{4}$ ) (Schanberg et al. $1968 \mathrm{a}, 1968 \mathrm{~b}$ ) considered a useful index of NA turnover in rat brain (Meek and Neff, 1973; Kohno et al. 1981), we reported that NA turnover increases in specific areas of rat brain including the hypothalamus, amygdala, hippocampus, thalamus, pons plus medulla oblongata and cerebral cortex, after the animals have been exposed to immobilization stress (Tanaka et al. in press) or tail shock under immobilization stress (Nakagawa et al. 1981). We also noted time-related differences in increases in NA turnover induced by stress; in particular, the most rapid and marked increase in NA turnover is observed in the hypothalamus (Tanaka 
et al. in press; Nakagawa et al. 1981). However, the significance of stress-induced increases in NA turnover remains controversial.

With the demonstration of endogenous opioid peptides (Hughes, 1975) and subsequent determination of several structures (Hughes et al. 1975; Simantov and Snyder, 1976; Li and Chung, 1976), numerous efforts have been made to clarify the roles of these peptides in the brain.

In addition, analgesia has been reported to follow stressful stimuli such as immobilization (Amir and Amit, 1978), foot shock (Akil et al. 1976; Madden et al. 1977) or cold water swim (Bodnar et al. 1978). This is believed to be due to opioids in the brain, since analgesia is attenuated by opioid antagonists such as naloxone.

Further, Rossier et al. (1977) and Guillemin et al. (1977) have demonstrated $\mathrm{ACTH}$ and $\beta$-endorphins increase concomitantly in the plasma of rats exposed to stress.

These findings suggest that opioids in the brain play a role in stress situations.

The present study investigates the effects of endogenous opioids by using their antagonist, naloxone (Martin, 1967) on stress-induced increases in NA turnover in the hypothalamus, which contains high concentrations of not only NA and MHPG$\mathrm{SO}_{4}$ (Kohno et al. 1981) but also endogenous opioids (Kobayashi et al. 1978; Barchas et al. 1978) and moderate densities of opiate receptors (Atweh and Kuhar, 1977). The hypothalamus is also the site of noradrenergic neurons which respond to stress more rapidly and markedly than in other areas of the brain (Tanaka et al. in press).

\section{Methods}

Male Wistar rats weighing $170-190 \mathrm{~g}$ were housed 4 to a cage $(265 \times 425 \times 150$ $\mathrm{mm}$ standard cage containing wood shav- ings) in a 12 hour (7:00 a. m. to 7:00p. m.) light/dark cycled room at constant room temperature $\left(24 \pm 1^{\circ} \mathrm{C}\right)$ and humidity $(50 \pm$ 10\%). Food and water were provided ad libitum.

Naloxone hydrochloride (the gift from Sankyo K.K. ) was dissolved in physiological saline, then $1 \mathrm{mg} / \mathrm{kg}$ or $5 \mathrm{mg} / \mathrm{kg}$, referring to the free base, was injected subcutaneously in a volume of $0.2 \mathrm{ml} / 100 \mathrm{~g}$ body weight.

Immobilization was employed as a stress procedure by enclosing animals in a flexible wire mesh $(3 \times 3 \mathrm{~mm})$ initially formed into a cone and then bent to conform to the size of the individual rats.

Rats were allocated to one of the following six groups. Those in the first three groups were injected with saline or with naloxone at $1 \mathrm{mg} / \mathrm{kg}$ or $5 \mathrm{mg} / \mathrm{kg} 70 \mathrm{~min}$ before sacrifice. The animals in the remaining three groups were exposed to 1 hour-immobilization stress $10 \mathrm{~min}$ after injection with saline or with the respective doses of naloxone. The former three groups served as controls for the latter three stressed-groups.

The rats were sacrificed by decapitation immediately after each treatment, and the hypothalamus was dissected out according to the method of Gispen et al. (1972) and stored at $-45^{\circ} \mathrm{C}$ until assayed. $\mathrm{NA}$ and MHPG-SO ${ }_{4}$ levels in the region were determined simultaneously by our fluorometric method (Kohno et al. 1979).

Student's t-test (two-tailed) was employed for a statistical analysis.

\section{Results}

Results are shown in Table 1. Immobilization stress caused significant decreases in hypothalamic NA levels in saline, naloxone $1 \mathrm{mg} / \mathrm{kg}$ and $5 \mathrm{mg} / \mathrm{kg}$ groups, compared to their respective controls. Naloxone alone decreased NA levels in a dose-dependent manner and the decrease by the drug 
TABLE 1

Effect of naloxone pretreatment on changes in noradrenaline $(N A)$ and

3-methoxy-4-hydroxyphenylethyleneglycol sulfate ( $\left.\mathrm{MHPG}-\mathrm{SO}_{4}\right)$ contents $(\mathrm{ng} / \mathrm{g})$ in the rat hypothalamus induced

by immobilization stress

\begin{tabular}{|c|c|c|}
\hline Treatment & NA & $\mathrm{MHPG}-\mathrm{SO}_{4}$ \\
\hline Saline & $2305.2 \pm 93.90$ & $280.1 \pm 10.97$ \\
\hline Saline + Stress & $1739.4 \pm 60.44^{\mathrm{a} * * *}$ & $483.9 \pm 26.82^{a * * *}$ \\
\hline Naloxone $1 \mathrm{mg} / \mathrm{kg}$ & $2268.0 \pm 87.29$ & $269.2 \pm 10.11$ \\
\hline Naloxone $1 \mathrm{mg} / \mathrm{kg}+$ Stress & $1658.1 \pm 70.55^{\mathrm{a} * * *}$ & $532.5 \pm 37.03^{a * * *}$ \\
\hline Naloxone $5 \mathrm{mg} / \mathrm{kg}$ & $1979.8 \pm 46.47 \mathrm{~b} * *$ & $254.4 \pm 10.55$ \\
\hline Naloxone $5 \mathrm{mg} / \mathrm{kg}+$ Stress & $1407.4 \pm 47.65 \underset{\mathrm{c} * * * *}{\mathrm{a} * * *}$ & $571.0 \pm 25.22 \underset{\mathrm{c} * * *}{\mathrm{a} * * *}$ \\
\hline
\end{tabular}

Each value indicates the mean \pm S.E.M. of 8 rats.

Statistical significance:

a: stress vs respective controls

b: vs saline control

c: vs saline+stress

Statistical significance levels are:

${ }^{*} \mathrm{P}<0.05, \quad * * \mathrm{P}<0.01, \quad * * * \mathrm{P}<0.001$

See text for detail.

at $5 \mathrm{mg} / \mathrm{kg}$ was statistically significant. The hypothalamic NA level in rats treated with $5 \mathrm{mg} / \mathrm{kg}$ of naloxone followed by stress was significantly reduced compared to levels in animals stressed after saline injection.

MHPG-SO ${ }_{4}$ levels in the hypothalamus in saline, naloxone $1 \mathrm{mg} / \mathrm{kg}$ and $5 \mathrm{mg} / \mathrm{kg}$ groups were significantly increased by immobilization stress compared to levels in the respective controls. Although naloxone alone tended to decrease the metabolite levels, no statistical significance was obtained compared to saline controls. The hypothalamic MHPG-SO $\mathrm{SO}_{4}$ level in stressed rats pretreated with naloxone at $5 \mathrm{mg} / \mathrm{kg}$ was significantly increased compared to that in stressed animals with saline.

\section{Discussion}

In the present study, immobilization stress caused both a significant decrease in NA level and an increase in $\mathrm{MHPG}-\mathrm{SO}_{4}$ level in the hypothalamus. This indicates that release of NA is enhanced in the hypothalamus by immobilization stress, as previously reported by us (Tanaka et al. in press).

Naloxone at $5 \mathrm{mg} / \mathrm{kg}$ alone significantly decreased the hypothalamic NA level and tended to decrease the MHPG-SO level, but not significantly. This seems to be due to an inhibitory action of the drug on catecholamine synthesis, as described by García-Sevilla et al. (1978).

In spite of the inhibitory effect of naloxone on catecholamine synthesis, the present study shows that pretreatment with naloxone at $5 \mathrm{mg} / \mathrm{kg}$ significantly enhanced the stress-induced increase in NA turnover in the hypothalamus; both the decrease in NA level and the increase in $\mathrm{MHPG}-\mathrm{SO}_{4}$ level caused by stress were significantly greater in rats pretreated with naloxone at $5 \mathrm{mg} / \mathrm{kg}$ than those with saline. Together with the findings that the hypothalamus contains high concentrations of opioids (Kobayashi et al. 1978; Barchas et al. 1978) and moderate densities of opiate receptors (Atweh and Kuhar, 
1977), enhancement of the stress-induced increase in NA release in the hypothalamus by naloxone seems to be due to blockade of opiate receptors by the drug. These receptors are the binding sites of endogenous opioid ligands of which release might be increased during stress. The idea that endogenous opioids released during stress play a role in the stress process is supported by reports that ACTH and $\beta$-endorphins are concomitantly released into the blood of stressed rats (Rossier et al. 1977; Guillemin et al. 1977). Further support is found in reports which show that various stresses, including immobilization (Amir and Amit, 1978), cause analgesia, which can be attenuated by naloxone in rats (Akil et al. 1976; Bodnar et al. 1978) and in humans (Willer and Albe-Fessard, 1980), or are accompanied by changes in stereospecific bindings of tritiated naloxone (Madden et al. 1977) or etorphin (Chance et al. 1977) in the rat brain.

Taken together with our previous report which showed that the hypothalamus contains very high levels of both NA and $\mathrm{MHPG}-\mathrm{SO}_{4}$ and that noradrenergic activity in the hypothalamus increases more markedly and rapidly than in other regions examined, we suggest there is a close relationship between opioid peptide system and noradrenergic system in the hypothalamus, specifically that opioid peptides are released to provide a protective or inhibitory role against increases in NA release or excessive release of NA caused by stress. This is reasonable, since in cerebral cortex recent evidence indicates that opiate receptors are localized presynaptically on terminals of noradrenergic neurons (Llorens et al. 1978) and that stimulation of these receptors by morphine or $\beta$-endorphin results in inhibition of NA release from their nerve terminals (Abilla and Langer, 1978).

The hypothalamus plays an important role in the regulatory function of the autonomic nervous system, the endocrine system, and emotion. Furthermore, naloxone is reported to induced tension-anxiety in human (Grevert and Goldstein, 1977) and to potentiate emotional responses in rats (Rodgers and Deacon, 1979; Green et al. 1979; File, 1980). Redmond et al. (1979) reported that a brain noradrenergic system might be involved in anxiety in monkeys. These data suggest that endogenous opioid peptides act to reduce emotion hightened by stress, i. e., to relieve anxiety or fear in animals exposed to noxious stimuli, in part, by attenuating the activity of noradrenergic neurons in the hypothalamus.

Multiple forms of opiate receptors have been proposed to be present in nervous tissue (Llord et al. 1977; Audigier et al. 1977; Terenius, 1977) and relatively higher concentrations of naloxone are required to antagonize effects mediated by some of these receptors (Lord et al. 1977). These studies suggest that the drug dosages used in our study are suitable as reported by Holtzman (1979) and adequate to block low affinity sites of these receptors (Audigier et al. 1977).

The assumption in the present study is that naloxone has no phramacological actions other than those related to the blockade of opiate receptors. However, Sawynok et al. (1979) pointed out that naloxone might have pharmacological actions unrelated to opiate receptor blockade. Dingledine et al. (1978) reported that naloxone may be an antagonist of $\gamma$ aminibutyric acid (GABA). The present finding cannot be explained by the antagonistic action of naloxone to GABA, since such an action appears when much larger doses of the drug are applied than those used in the present study.

Barchas et al. (1978) suggested that endorphins might well play critical roles in behavioral and emotional responses to the environment, if these peptides were part of the basic systems which modulate responses to pain and stress. 
The present study supports the view proposed by Barchas et al. (1978) and reveals, indirectly, that endogenous opioid peptides in the hypothalamus are partially involved in the stress process in this region. The idea is further supported by our recent finding using morphine (unpublished observation), even when actions of naloxone unrelated to the opioid peptide system are taken into consideration.

Acknowledgement: We are grateful to Miss Shigeko Takeda for her skillful technical assistance and to Dr. Tadashi Nishikawa of the Department of Pharmaocolgy, Kurume University School of Medicine for stimulating discussion. Expressions of appreciation are also due to Sankyo K.K. and to Nippon Roche K.K. for generous supplies of naloxone hydrochloride and MHPG-SO $\mathrm{S}_{4}$, respectively.

\section{References}

Abilla, S. and Langer, S.Z. (1978). Morphine and $\beta$-endorphin inhibit release of noradrenaline from cerebral cortex but not of dopamine from rat striatum. Nature, 271, 559560.

Akil, H., Madden, J., Patrick, R.L. and BarCHAS, J. D. (1976). Stress - induced increase in endogenous opiate peptides: Concurrent analgesia and its partial reversal by naloxone. In Opiate and Endogenous Opiate Peptides, ed. Kosterlitz, H. W., pp. 63-70, Amsterdam: North-Holland.

Amir, S. and Амгт, Z. (1978). Endogenous opioid ligands may mediate stress-induced changes in the affective properties of pain related behavior in rats. Life Sci. 23, 1143-1152.

Atweh, S.F. and Kuhar, M. J. (1977). Autoradiographic localization of opiate receptors in rat brain. II. The brain stem. Brain Res. 129, 1-12.

Audigier, Y., Malfroy - Camine, B. and Schwartz, J.C. (1977). Binding of ${ }^{3} \mathrm{H}-\mathrm{Leu}$-enkephalin in rat striatum: Partial inhibition by morphine or naloxone. Europ. J. Pharmcol. 41, 247-248.

Barchas, J.D., Akil, H., Elliot, G.R., Holman, R. B. and WAtson, S. J. (1978). Behavioral neurochemistry: Neuroregulators and be havioral states. Science, 200, 964-973.

Bodnar, R. J., Kelly, D. D., Spiaggia, A., EhrenBerg, C. and Glusman, M. (1978). Dose-dependent reductions by naloxone of analgesia induced by cold-water stress. Pharmacol. Biochem. Behav. 8, 667-672.

Chance, W. T., White, A.C., Krynock, G.M. and Rosecrans, J.A. (1977). Autoanalgesia: Behaviorally activated antinociception. Europ. J. Pharmacol. 44, 283-284.

Dingledine, R., Iversen, L. and BREUKer, E. (1978). Naloxone as a GABA antagonist: evidence from iontophoretic, receptor binding and convulsant studies. Europ. J. Pharmacol. 47, 19-27.

FILE, S.E. (1980). Naloxone reduces social and exploratory activity in the rat. Psychopharmacology, 71, 41-44.

Garcia-Sevilla, J.A., Ahtee, L., Magnusson, T. and CARlsson, A. (1978). Opiate-receptor mediated changes in monoamine synthesis in rat brain. J. Pharm. Pharmacol. 30, 613621.

Gispen, W.H., Schotman, P. and de Kloet, E. R. (1972). Brain RNA and hypophysectomy: a topographical study. Neuroendocrinology, 9, 285-296.

Green, E. J., Issacson, R. ¿̇L., Dunn, A. J. and LANThoRn, T.H. (1979). Naloxone and haloperidol reduce grooming occurring as an after-effect of novelty. Behav. Neural. Biol. 27, 546-551.

Grevert, P. and Goldstein, A. (1977). Effects of naloxone on experimentally induced ischemic pain and on mood in human subjects. Proc. Natl. Acad. Sci. U.S. A. 74, 1291-1294.

Guillemin, R., Vargo, T., Rossier, J., Minick, S., Ling, N., Rivier, C., Vale, W. and Bloom, F. E. (1977), $\beta$-Endorphin and adrenocorticotropin are secreted concomitantly by pituitary gland. Science, 197, 1367-1369.

Holzman, S.G. (1979). Suppression of appetitive behavior in the rat by naloxone: Lack of effect of prior morphine dependence. Life Sci. 24, 219-226.

Hughes, J. (1975). . Isolation of an endogenous compound from the brain with pharmacological properties similar to morphine. Brain Res. 88, 295-308.

Hughes, J., Smith, T.W., Kosterlitz, H.W., Fothergill, L.A., Morgan, B. A. and Morris, H.R. (1975). Identification of two related 
pentapeptides from the brain with potent opiate agonist activity. Nature, 258, 577579.

Kobayashi, R. M., Palkovits, M., Miller, R. J., Chang, K. J. and Cuatrecasas, P. (1978). Brain enkephalin distribution is unaltered by hypophysectomy. Life Sci. 22, 527-530.

Kohno, Y., Matsuo, K., Tanaka, M., Furukawa, T. and NAGASAKI, N. (1979). Simultaneous determination of noradrenaline and 3-methoxy-4-hydroxy phenylethyleneglycol sulfate in discrete brain regions of the rat. Anal. Biochem. 97, 352-358.

Kohno, Y., Tanaka, M., Nakagawa, R., Toshima, N. and NAGASAKI, N. (1981). Regional distribution and production rate of 3-methoxy4 -hydroxy phenylethyleneglycol sulphate (MHPG-SO 4 ) in rat brain. J. Neurochem. 36, 286-289.

LI, H. L. and Chung, D. (1976). Isolation and structure of an untriakontapeptide with opiate activity from camel pituitary glands. Proc. Natl. Acad. Sci. U.S.A. 73, 11451148.

Llorens, C., Martres, M. P., Baudry, M. and Schwartz, J. C. (1978). Hypersensitivity to noradrenlaine in cortex after chronic morphine: Relevance to tolerance and dependence. Nature, 274, 603-605.

Lord, J. A. H., Waterfield, A. A., Hughes, J. and Kosterlitz, H. W. (1977). Endogenous opioid peptides: Multiple agonists and receptors. Nature, 267, 4.95-499.

Madden, J.I. V., Akil, H., Patrick, R.L. and BARCHAS, J.D. (1977). Stress-induced parallel changes in central opioid levels and pain responsiveness in the rat. Nature, 265, 358360.

Martin, W. R. (1967). Opiate antagonists. Pharmacol. Rev. 19, 463-496.

Meek, J.L. and Neff, N.H. (1973). The rate of formation of 3-methoxy-4-hydroxyphenylethyleneglycol sulphate in brain as an estimate of the rate of formation of norepinephrine. J. Pharmacol. Expt. Ther. 184, 570575.

Nakagawa, R., Tanaka, M., Kohno, Y., Noda, Y. and NAgAsaki, N. (1981). Regional responses of rat brain noradrenergic neurones to acute intense stress. Pharmcol. Biochem. Behav. 14, 729-732.
Redmond, Jr. D.E., Huang, Y.H., Baulu, J. and Gold, M.S. (1979). Evidence for the involvement of a brain norepinephrine system in anxiety. In Catecholamines: Basic and Clinical Frontiers, vol. 2, ed. Usdin, E., Kopin, I. J. and Barchas, J., pp. 1693-1695, New York: Pergamon Press.

Rodgers, R. J. and Deacon, R.M. J. (1979). Ef fect of naloxone on the behavior of rats exposed to a novel environment. Psychopharmacology, 65, 103-105.

Rossier, J., French, E. D., Rivier, C., Ling, N., Guillemin, R. and Bloom, F.E. (1977). Footshock induced stress increases $\beta$-endorphin levels in blood but not brain. Nature, 270, 618-620.

Sawynok, J., Pinsky, C. and LaBella, F.S. (1979). Minireview on the specificity of naloxone as an opiate antagonist. Life Sci. 25, 1621-1632.

Schanberg, S.M., Schilkraut, J. J., Breese, G. R. and Kopin, I.J. (1968 a). Metabolism of norepinephrine- $\mathrm{H}^{3}$ in rat brain.-Identification of conjugated 3-methoxy-4-hydroxyphenylglycol as the major metabolite. Biochem. Pharmacol. 17, 247-254.

Schanberg, S. M., Breese, G. R., Schidkraut, J. J., Gordon, E. K. and Kopin, I. J. (1968 b). 3-Methoxy-4-hydroxyphenylglycol sulfate in brain and cerebrospinal fluid. Biochem. Pharmacol. 17, 2006-2008.

Simantov, R. and Snyder, S.H. (1976). Morphine-like peptides in mammalian brain: Isolation, structure elucidation, and interactions with the opiate receptor. Proc. Natl. Acad. Sci. U.S. A. 73, 2515-2519.

Stone, E. A. (1975). Stress and catecholamines. In Catecholamines and Behavior, ed. Friedhoff, A. J., pp. 31-72, New York: Plenum Press.

Tanaka, M., Kohno, Y., Nakagawa, R., Ida, Y., Takeda, S. and Nagasaki, N. (1982). Timerelated differences in noradrenaline turnover in rat brain regions by stress. Pharmacol. Biochem. Behav. 16 (in press).

Terenius, L. (1977). Opioid peptides and opiate differ in receptor selectivity. Psychoneuroendocrinology, 2, 53-58.

Willer, J. C. and Albe-Fessard, D. (1980). Electrophysiological evidence for a release of endogenous opiates in stress-induced 'analgesia' in man. Brain Res. 198, 419-426. 